\title{
510 ねじれ :〈さび回位型変形場を有する結晶モデルの多重すべり変形と再結晶粒成長の検討 Multiple slip deformation and generation of recrystalization unclei in crystal models with deformation field of wedge and twist-type disclinations
}

\author{
正 大橋 鉄也 (北見工大) $\bigcirc$ 学 島津 侑宜（北見工大院）
}

Tetsuya OHASHI, Kitami Institute of Technology

Yuki SHIMAZU, Graduate Student, Kitami Institute of Technology

\begin{abstract}
金属材料の塑性変形は，結晶粒に生じるすべり変形や双晶 変形などの組み合わせであり，金属多結晶では粒界を通した 変形拘束の相互作用が生じる.この結果，粒界近傍には不均 一な変形が生じ, それに伴うひずみ勾配に応じて幾何学的に 必要な転位(以後 GN 転位と略する)が蓄積する．金属微視組 織中に蓄積する GN 転位は再結晶核の発生に重要な役割を果 たしていると考えられている，現象論的には，再結晶核は結 晶粒界の近傍やとくに結晶粒界の 3 重線や 4 重点の近傍に多 数形成されることが知られており, 再結晶開始前の微視組織 の平均粒径も，再結晶組織に大きな影響を及ぼすことが良く 知られている。これまで我々は，寸法の異なる粒界 3 重線モ デルを作成し，GN 転位の蓄積箇所や再結晶核発生箇所を検 討した. 本研究ではくさび回位型及び称じれ回位型変形場を 持ち，モデル寸法が異なる 3 重結晶モデルを用いて、GN 転 位のデータに基づいて再結晶核を発生させて, その分布の特 長について検討するとともに, 再結晶核の成長の初期段階に 関するMonte Carlo(以後 MCと略する)シミュレーション(1)を行 亏.
\end{abstract}

\section{2. 解析モデルと解析方法}

くさび回位型及び称じれ回位型変形場を持つ三重結晶モ デルを Fig. 1 に示す. 以降 Fig.1(a)のモデルを $W_{\text {large }}$-model, (b) のモデルを $\mathrm{T}_{\text {arge-model }}$ と呼ぶ. これらモデルに含まれる3つ の結晶粒における主すべり系すべり面の配置も Fig. 1 に示し た. 図に示されているように，す心゙り面法線方向ベクトルの $\mathrm{z}$ 方向成分が 0 になるように結晶方位を選択した。 またこ れらのすべり系のすべり方向ベクトルも $\mathrm{z}$ 成分が 0 となるよ らに決定した. すべり面法線方向と $\mathrm{y}$ 軸とのなす角, すべり 方向ベクトル $\mathrm{b}$ ，すべり面法線ベクトル $v$ の $\mathrm{x}, \mathrm{y}$ 成分の值 および，次式で与えられるシュミットテンソル

$$
P_{i j}=\frac{1}{2}\left(b_{i} v_{j}+v_{i} b_{j}\right)
$$

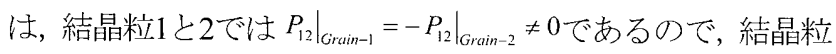
3による拘束がなければ，このすべり系が活動するとx-y-z座 標系に関するせん断ひずみも $\left.\varepsilon_{x y}\right|_{\text {Grain-1 }}=-\left.\varepsilon_{x y}\right|_{\text {Grain-2 }} \neq 0$ となる. 結 晶粒3の結晶方位は結晶粒1の結晶を軸で $180^{\circ}$ 回転させた ものを選んだ. Fig. 1(a)のW 方向に重水，結晶粒了を（ $\mathrm{z}$ 軸方向から見て）これの左に隣 接するように配した．この時，粒界3重線を中心としたくさ び回位型の変形場が形成される(2). 一方Fig.1(b)の $\mathrm{T}_{\text {large- }}$ modelで は，結晶粒3を結晶粒1，2の手前に隣接するように配した。 このとき，3つの結晶粒の主す心゙り系が活動すると, 粒界3重 線を中心としたねじれ回位型の変形場が形成される(2).この2
種類の3重結晶の塑性変形を結晶塑性解析プログラムCLP ${ }^{(3)(4)}$ を用いて解析する. 本研究では $W_{\text {large }}$-model及び $T_{\text {lage }}-$ modelの寸 法を $200 \times 200 \times 100[\mu \mathrm{m}], 100 \times 200 \times 200[\mu \mathrm{m}]$ とし， Fig.1に示した2 つのモデル寸法を $1 / 10$ の $20 \times 20 \times 10[\mu \mathrm{m}]$ と $10 \times 20 \times 20[\mu \mathrm{m}]$ に縮小 LたW $\mathrm{w}_{\text {snall }}$-model、 $\mathrm{T}_{\text {small }}$ modelも作成した. 各モデルとも2048の 有限要素に分割し，材料は弾性異方性を無視できるもの(弾 性コンプライアンス $\left[\mathrm{m}^{2} / \mathrm{N}\right]: \mathrm{S}_{11}=1 \times 10^{-11}, \mathrm{~S}_{22}=-0.25 \times 10^{-11}$, $\left.\mathrm{S}_{44}=2.5 \times 10^{-11}\right)$ を用いた。 また，両モデル上下端面に均一に分 布する圧縮負荷を与え，ひずみが $20 \%$ まで解析を行った。

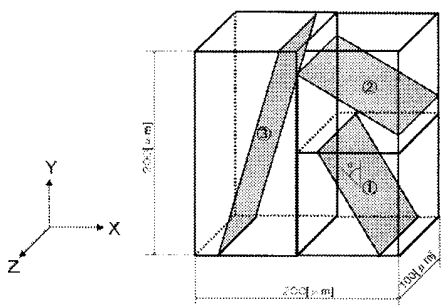

(a)

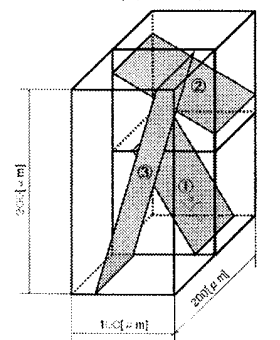

(b)

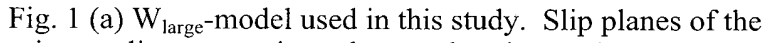
primary slip systems in each crystal grain are shown.

(b) $\mathrm{T}_{\text {large }}$-model used in this study. Slip planes of the primary slip systems in each crystal grain are shown.

いくつかの実験結果俚多重すべりの程度が再結晶核の発生 に関与していることを示唆している.このことは, 多重すべ りが生じると異なるす心゙り系のGN転位が切り合い，絡み合 うために, 材料中に容易に散逸しない形でエネルギーが蓄積 し，それが再結晶核の発生に寄与するためであると考えるこ とができる．また，再結晶核と母相との界面が安定に存在す るために，複数の寸べり系上のGN転位群がなければならな いとする考え方もある(5). 我々はそれぞれのすべり系に蓄積 したGN転位の量および, 複数のすべり系上のGN転位の重ね 合わせの強さを表す指標として, 次の3つの量 $\tilde{I}_{1}, \tilde{I}_{2}, \tilde{I}_{3} に$ ついて検討してきた ${ }^{(6)}$.

$$
\begin{aligned}
& \tilde{I}_{1}=\frac{\sum_{i} \mid \rho_{G}^{(i)} \|}{\left.\sum_{i} \rho_{S}^{(i)}\right|_{0}} \\
& \tilde{I}_{2}=\frac{\sum_{i} \sum_{j} \omega_{2}^{(i j)}\left\|\rho_{G}^{(i)}\right\| \times\left\|\rho_{G}^{(j)}\right\|}{\left.\sum_{i} \sum_{j} \omega_{2}^{(i j)} \rho_{S}^{(i)}\right|_{0} \times\left.\rho_{S}^{(j)}\right|_{0}} \\
& \tilde{I}_{3}=\frac{\sum_{i} \sum_{j} \sum_{k} \omega_{3}^{(j k)}\left\|\rho_{G}^{(i)}\right\| \times\left\|\rho_{G}^{(j)}\right\| \times\left\|\rho_{G}^{(k)}\right\|}{\left.\sum_{i} \sum_{j} \sum_{k} \omega_{3}^{(j k)} \rho_{S}^{(i)}\right|_{0} \times\left.\rho_{S}^{(j)}\right|_{0} \times\left.\rho_{S}^{(i)}\right|_{0}}
\end{aligned}
$$

ここで// $\rho_{\mathrm{G}}^{(\mathrm{i})} / /$ はすべり系iでのGN転位密度のノルムの值, 
$\rho_{s}^{(i)}$ はすすべり系棌の初期転位密度 $\omega_{2}^{(j)}, \omega_{3}^{(i k)}$ はすべり系の組 み合わせによって值が変わる重み係数である(の).

結晶塑性解析の結果から得られた $\tilde{I}_{1}, \tilde{I}_{2}$, または $\tilde{I}_{3}$ の值が 閾值より大きな箇所に再結晶核を発生させることにする.こ の時, 再結晶核半径は $\tilde{I}_{1}, \tilde{I}_{2}$ ，または $\tilde{I}_{3}$ の値に比例するもの とした，再結晶粒成長のMCシミュレーションでは，Fig. 1の モデルを87808個のセルに分割した。

\section{3. 結果と考察}

Fig. 2,3はW $\mathrm{W}_{\text {kage }}$-modelおよび $\mathrm{W}_{\text {small }}$-modelについて再結晶核発 生の閾値を $\tilde{I}_{i}>0.2(i=1,2$ or 3$)$ としたときの再結晶核の分 布である. $\tilde{I}_{1}>0.2$ を再結晶核の発生条件とした場合には初 期結晶粒径の大きさが違っていても, 核発生のしかたに違い が見られないが，多重すべりが核発生に必要であると考えた 条件, すなわち $\tilde{I}_{2}>0.2$ または $\tilde{I}_{3}>0.2$ を核発生条件とすると， 再結晶前の結晶粒の寸法（初期結晶粒径）が小さな方が多 くの核が発生することがわかる.

Fig. 4, 5は再結晶核の発生条件を $\tilde{I}_{i}>3(i=1,2$ or 3$)$ とした ときの， $\mathrm{T}_{\text {krgec }}$-modelおよび $\mathrm{T}_{\text {smal }}$-modelにおける再結晶核の分布

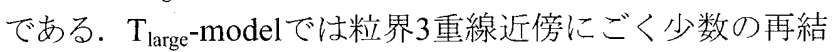
晶核が発生したが， $\mathrm{T}_{\text {small }}$-modelでは $\tilde{I}_{1}, \tilde{I}_{2}, \tilde{I}_{3}$ のどの指 標を用いてもモデルの広い範囲にわたって再結晶核が発生 した.これは $\mathrm{T}_{\text {small }}$-model と $\mathrm{T}_{\text {large }}$-modelでGN転位の蓄積量 に大きな差があるためであり，初期結晶粒径が影響して いる.

全てのモデルで再結晶核粒径は粒界3重線近傍では大きく， 粒界3重線から離れるにつれ粒径が小さくなった。これは粒 界3重線近傍のひずみエネルギ一の蓄積量が多いためである.

Fig.6(a),(b)は, $\mathrm{T}_{\text {large }}$-model及びT $\mathrm{s}_{\text {small }}$-modelについて $\tilde{I}_{3}>3$ を再結晶核発生条件とし，そこからの成長に関して100ステ ップのモンテカルロシミュレーションを行なった結果であ る. $\mathrm{T}_{\text {large- }}$-modelでは粒界 3 重線近傍から少数の大きな再結 晶粒が成長している一方, $\mathrm{T}_{\text {small }}$-modelでは多数の小さな 再結晶粒が一度に形成されてモデル下方の部分を埋め 尽くしている。再結晶粒の成長は結晶粒界や粒界3重線 近傍から始まることや，初期結晶粒径が小さな場合には 再結晶核の発生は粒界近傍に限らないことなどが知ら れており, 本研究ではこれらの実験的な知見を数值的に 再現することが出来た。
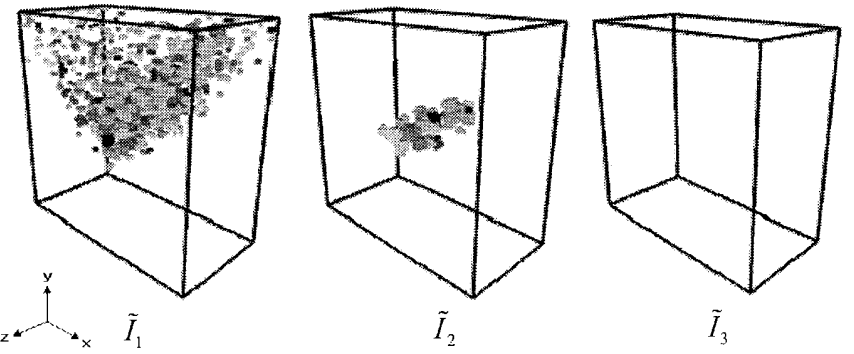

Fig. 2 Generation of recrystalization nuclei in $\mathrm{W}_{\text {large-model. }}$
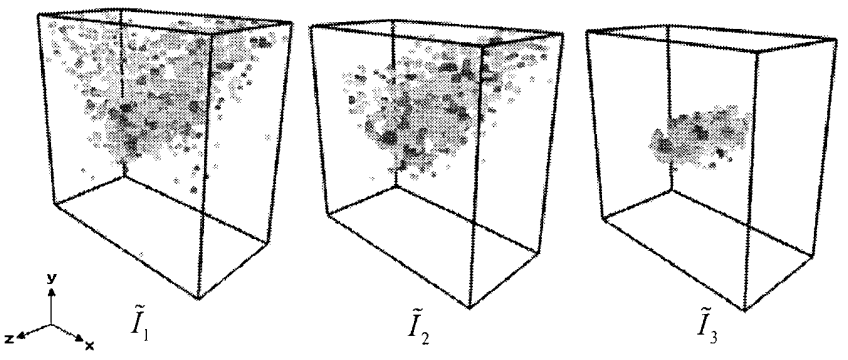

Fig. 3 Generation of recrystalization nuclei in $\mathrm{W}_{\text {small }}$-model.
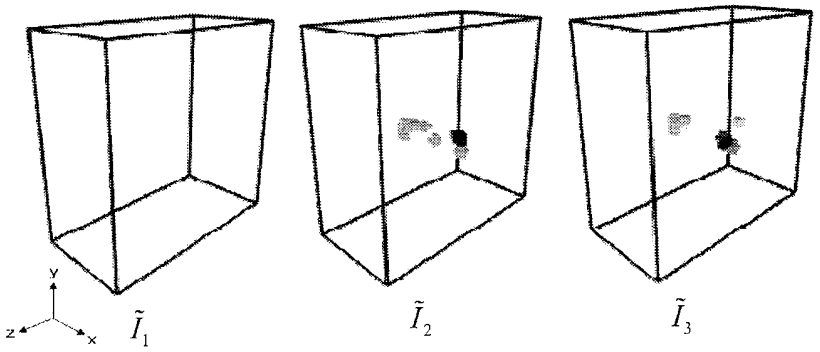

Fig. 4 Generation of recrystalization nuclei in $\mathrm{T}_{\text {large }}$-model.
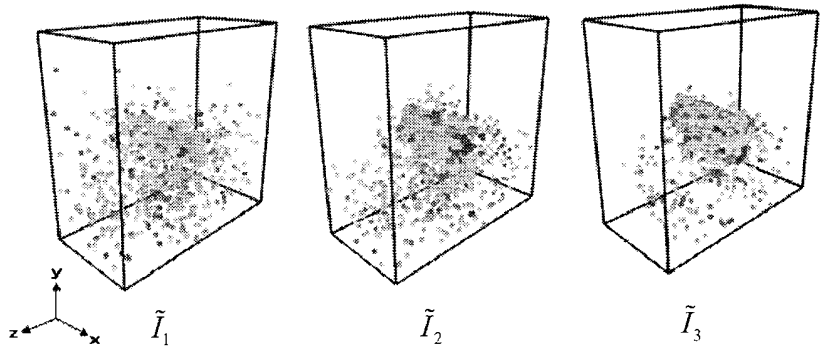

Fig. 5 Generation of recrystalization nucleiin $\mathrm{T}_{\text {small-model. }}$

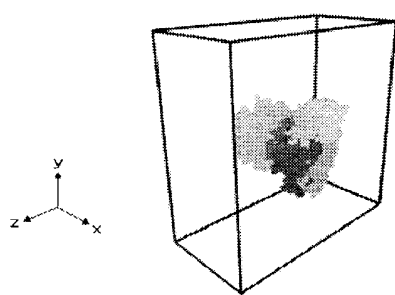

(a)

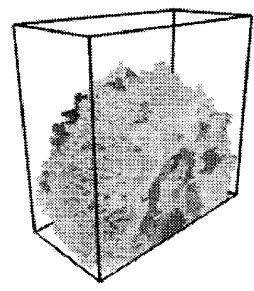

(b)
Fig. 6 Monte Carlo simulation results of recrystalization in (a) $\mathrm{T}_{\text {large-model and in (b) } \mathrm{T}_{\text {small }} \text {-model. }}$

\section{4. 結 言}

くさび回位型及びねじれ回位型変形場を持ち，モデル寸法 が異なる4種類の3重結晶モデルを用いて，GN転位の蓄積を 求め, そのデー夕に基づいて発生させた再結晶核の分布とそ の成長について検討した. その結果, 再結晶現象の特徵とし て報告されているいくつかの事柄を数值的に再現すること ができた.

\section{5. 参考文献}

(1)斉藤良行, 組織形成と拡散方程式, コロナ社, p118-124

(2)Ohashi, T, Sato, M, and Shimazu, Y, Materials Science

Forum Vols. 654-656,2010, p1283-1286

(3) Ohashi, T., 1994, Phil. Mag., A70, 793

(4) Ohashi, T., 1997, Phil. Mag., Lett., 75, 51

(5) M. Tagami, K. Kashihara, T. Okada and F. Inoko, J. Japan Inst. Metals 41(2000) 535-542

(6) 大橋，栗原，2008年度，計算力学講演会論文集，P395-396 